\title{
と畜検査データのデータベース化*1
}

\author{
鈴木 亘*2
}

\section{Data Base for Inspection Data of Slaughtered Animals}

\author{
Wataru SUZUKI
}

Hamamatsu Meat Inspection Office, 986, Uenishi, Hamamatsu, Shizuoka 435, Japan.

\section{1.はじめに}

浜松市食肉衛生検査所では, と畜検査データのパ ーソナルコンピュータ（以下，パソコン）による独 自の集計システムを実現している。パソコンによる と畜検査データの集計は，幾つかの検查所でも採用 されており，沉用機とのインターフェース，簡単か つ迅速なデータ抽出によるフィードバックへの活用 など、簡素なシステムであるにもかかわらず，大き な発展性を持ち合わせたシステムである。

\section{2. システム誕生の契譏}

浜松市と畜場は，昭和 57 年度に国・県の補助によ $\eta$, 食肉地方卸売市場併設と畜場に改築され, 静岡 県西部地域への食肉供給基地として，事業規模が大 きく拡大された。昭和53～57年における豚の年平均 と畜頭数は 12 万 6 千頭であったが, 昭和 58,59 年は, 約 14 万頭，60年には 17 万頭を越之，61年以降は毎年 19 万頭を越之常時 20 万頭に迫り，昭和62年は，20万 頭を越えている。今後とも，と畜頭数は，その伸び 率は低下するものの確実に増加することが予想され ている。

当検査所のと畜検查デー夕の電算化は, まさに, この飛躍的と畜頭数増加の直前, 昭和 58 年に実現し たものである。

従来, と畜検查結果の記録に, 獣医師 1 名が記録

*1 第20回シンポジウム：獣医学領域におけるアプリケー ションプログラムを用いた情報処理

*2 浜松市食肉衛生検査所( T435 浜松市上西町986)
係として内臟検査に張りついていた。記録は，家畜 1 頭毎に収集され，その集計に費やす労力は，単に 煩わしいもの以外の何者でもなかった。また，客観 的に見ても，専門家たる獣医師が単なる数字の集計 に翻弄されているのは，好ましいものではない。

山本所長は，昭和 58 年に検查所へ再任されると同 時に,この事態を解消させる目的の電算化プロジェ クトを発足させた。

私は，昭和59年の異動により保健所より，食肉衛 生検査所に配属され，それを契機に新メンバーによ る第 2 次電算化プロジェクトが発足した。私は, 浜 松市中央卸売市場の検查室勤務時代に，パソコンを 利用した毒性検査システムを完成させた経験があっ たので，それを活かしてシステム全般の設計を担当 した。

\section{3. システム設計}

異動直後より，システム設計を行うことになった が, 当然, と玄検查そのものの知識は殆ど無いに等 しいものであったので，と畜検査全般を学びながら， その業務の特殊性と慣習などを特に意識してシステ ム設計を進めることにした。

システム設計には, 当然達成すべき次のような目 的がある。

(1)検查員の煩わしさの解消

「煩わしさの解消」とは, 即ち省力化のことであ るが，財政サイドはこれを単純に「合理化（人員削 減)」と解釈している。これは，非常に多くの問題を 含んでいるが，そのことについては，後述したいと 
思う。私は，と畜頭数増加が予測される折りでもあ $\eta$ ，単純に,「と畜検査員をこの機械的作業から開放 し獣医師らしい業務に復帰させる」ことを目的にシ ステムを設定した。

(2)処理の迅速化

データの集計作業の「迅速化」は, 必然的に達成 されるはずである。ただし，デー夕収集（入力）作 業もこの対象であることを見逃してはならない。

(3)蓄積されたデー夕の活用

山本所長は早くから「データの活用」に着目して いたが、実を言うと，私は，殆ど眼中には置いてい なかった。つまり, 省力化に比べたら二の次程度に しか考えていなかった。これは, システムを実現さ せることが必至の条件で，そこまで考える余裕がな かったことにもよる。

ここで, 電算化の目的は,「省力化」と「高度化」 の 2 つがあることに気が付いた。私は，「省力化(現 状解消)」だけを目的に, 所長は，「高度化（生産サ イドに对するフィードバックだけでなく，獣医学へ の応用を含む)」も含めて考えていたことになる。

目的（実は，思惑の違いがあったにも拘らず）を 一応設定したので，その具体的実現方法を検討した。

(1)登録すべき内容と保存方法

先ず，登録すべき内容について述べる。従前行っ ている集計内容を包含することは当然であるが,こ こで常のことながら、「折角コンピューター化するの だから，もっと多くのデー夕を登録できるようにし たい。」と言う希望が発生する。具体的には，家畜の より多くの性状（色, 性別, 種類, 年令, 蓄主, 飼 育歴など), より多くの検查項目 (病理組織学的判定 結果項目, 血液検查, 理化学検查及び細菌学的検查 結果の詳細な情報など）を入れたいと言うことであ る。つまり高度化の一環である。至極当然の要求で はあるが，私はそれまでに見聞きした経験からここ れは非常に危険な要素を含んだ要望であることを知 っていた。私は, 省力化と高度化とは, 相反するテ 一マと考えている。高度化が目的なら多少の手間が 掛かっても問題ないであろうが, 私の目的は, 省力 化だけに置いていたので,この要求に次のように応 えることにした。

「それは可能ですが, 誰が何時, どのようにそれ を入力するのですか？」

未だシステムの実物を見たことのない検查員にと っては, この問いは非常に恐怖を起こさせるもので あったようで,この要求は一瞬に消え去った。ある
意味で, 私がこのシステムの能力限界を設定してし まったことになるが, 相当の確信をもって, 敢えて, 登録項目の增加は行わないことにした。その理由は, 現状だけで十分なデー夕を記録していると考えたか らである。

また，それとは異なる次元で，登録項目の増加に はもう一つの問題があった。それはデー夕の蓄積方 法である。

蓄積されたデー夕は，その活用の有無に関わり無 くフロッピーディスク (以下, FD) で保存すること を想定していた。年間最大登録家畜数の設定は, シ ステム計画を行っていた前年58年のと畜頭数が前述 の通り14万頭であり，設計時点の 2 倍は必要である と見込んでいたので，30万頭とした。当然これ全部 を 1 枚の FDに保存することは不可能であり，何枚 かの FDに分割して保存することになるが，容易に 考之付くことは, 12 分割, 即ち 1 力月を 1 枚の FDに 保存することである。そうすると，1枚には 2 万 5 千頭を登録することになる。FD 1 枚のデー夕量は ご存知の通り $1 \mathrm{M}$ バイトであるから，1頭当たりに 与えられる容量は，40バイトになる。0から255の範 囲のデータなら 40 件, それ以上の範囲のものなら, 僅か20件のデータのバックを行い，これに詰め込む 自信はあった。実際には，FDの全容量を家亩デー夕 だけに割り当てることは不可能で, 結果としては 1 頭当たりのデー夕容量は36バイトになっている。

(2)病変, 申請者名のコード化

コード化は，登録すべき内容と並行して検討される ものである。コード化できる内容は，入力，集計作 業上の便宜を図り，さらにデー夕領域を節約する意 味からも極力コード化すべきである。コード化すべ き項目は幾つかあったが, その内, 特に問題となっ たのは，病変のコード化である。

現在, 全国食肉衛生検查所協議会でも遅れ馳せな がら, 病変コードの統一を検討しているが, その作 業は難行している。その最も大きな理由として, コ 一ドの桁に意味を持たせようとしていることと，あ らゆる病名を網羅しようとしていることを挙げるこ とができよう。

統一コードである以上, 病名数が多くなるのは仕 方無いにしても，桁位置に意味を持たせようとする のは，それがテクニックの一つではあるにしても， それに拘わり過ぎると大きな犠牲（時間と労力）を 払うことになりる。

病名のコード化は，と畜検查新人の私にとっては 
難題であったので, ベテラン検査員にすべてお任せ した。しかし, 逆に, ベテラン検査員は, コンピュ 一タにおけるコードの意味が理解できなかったので, 私はつぎのように依頼した。

「とにかく，記録したい病名を列記して下さい。 順序は問いませんので，好きなように並べてくださ い。」

私は，数千一万単位を想定していたが，予測に反 し，その推奨病名数は，250程度のものであった。コ 一ド化をお願いした検査員 (石川静馬) のコンセプ トは,「全ての病名が必要な訳ではない, と畜検查で 見つけられる病名だけでよい。と畜検査は, 病理解 剖学に基づくマクロ検査が主体であり, 肉眼で識別 できる範囲の病名で良く，また臨床症状名は不要で ある。と, 言うものであった。最終的に, 後述の入 力方法との兼ね合いもあり, 病変数は 400 , 病名コー ドの配列順序，桁位置には一切意味を持たせず，集 計に際しては別途参照テーブルを作成する方法を採 用した。我々は, この病変コードを完成するのに,

1カ月程度を費やしたにすぎなかった。

本システムは, この病名コードの為にあると言っ ても過言ではない。このコード化に失敗すると禍根 を残す事になるが，このべテラン検查員の勝れた洞 察力と合理主義は, 私の目的にも合致し, 最高のコ 一ド化が達成できたと自負している。完成から 5 年 を経過した現時点でも, 何ら遜色無い病変コードで あることを強調しておきたい。

(3)出力すべき内容と出力方法

出力すべき内容は，それ程問題にはならない。現 在行っている集計書類 (報告書) を出力させるだけ のことである。登録項目を增やさないことに決定し ているので, 新たに出力帳票が增えることもない。 ただ，その帳票の集計要領（目的）を理解さえすれ ば済むことであった。

一つだけ特殊な条件は, 荷受けである経済連への 報告は，いずれFD を媒体として行うことを想定し ていたことである。経済連は，汎用機を用いていた ので 8 インチ FDが必須であった。

(4)入力手段

入力手段は, システム設計上当初から最大の慗案 事項であった。システムの目的が省力化である以上， 入力に手間と時間が掛かっては意味のないものにな ってしまう。財務会計などでは，入力するデータは，

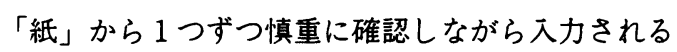
が, と畜検查デー夕は, 検査現場で常時発生するも
のでこれをいちいち紙に記録し，検查終了後に入 カしていたのでは, 何ら省力化にはならないので, 最初から即時入力を想定し, その手段を模索した。 この頃でも，音声入力は既に市販品として存在し ていたが，その識別能力は，我々の欲するレベルに は程遠いもので, 財政サイドに立てば, 人員削減の 目的に適うものであったが, 私達は相当早い時点で, 音声入力には見切りをつけている。音声入力でなく， 即時入力を実現する方法として私達は, オペレータ 方式を採用した。無線機を使用して検查現場で発生 したと畜検查データは, 事務所に報告され, オペレ ータにより直ちにコンピュータに入力される。

ここで, 問題になるのはキーボードである。多種 多様のデータを標準のキーボードで, リアルタイム に入力するのは至難の技であることから，多項目入 力装置（コードセレク夕）を探し出した。コードセ レクタは, 1 面80個 (シフトキーを併用すれば160個) の項目を13面, 即ち, 1,000 項目以上のコードを 1 キ 一で入力することができる装置である。また，キー 表示は，鉛筆で自由に書き込むようになっているの で, 病名や申請者名などは漢字で見やすく表現でき る。

病名コード数を 400 としたのは, コードセレクタの 5 ページを割り当てた結果で $(80 \times 5=400), 400$ と いう数に深い意味は無い。

(5)機種選定と開発言語

最後に機種選定と開発言語の指定について述べる。 これは最初から沉用パソコンと BASICと私は決め ていた。スピードとデータ量（そして信頼性）の上 で, オフコン (ここでのオフコンの意味は，非常に 感覚的なものなのであるが) でなくて大丈夫かとい う声もあったが, 私は融通の利かない汎用機より,

(我々の使用環境では) パソコンの方の価値を信じ ていたのでパソコンを押し通した。結局これは正し かった（と言うより，そのように仕向けた）訳で, 現在では，全ての検查員が市販プログラムを駆使し て，自由にパソコンを活用している。

また, 開発言語は, BASIC を指定した。データの パックの為のビット操作, コードセレクタ, マウス など周辺装置の $1 / 0$ 操作など, 文字列データの取り 扱いが主である高級言語では, 返って難しいと考之 たからであるが, 最大の理由は, 最終的に独自でプ ログラムを作らなければならないだろうと確信して いたので, 当時私が理解できるコンピュー夕言語で あった BASIC を指定した。 
現時点なら, 流行のCか Pasacal で作成してみた いところである。デー夕構造の定義や,ビット操作, メンテナンスなど, これらの言語の方が開発しやす い面をもっている。

\section{4. 実現}

実際のシステム開発は，その責任を明確にする上 でも外注とした。その経費算出を行い財政当局の承 諾も得られ, 予算計上が実現して, 翌年 4 月から実 際の発注・開発となった訳であるが, プログラム開 発は難行した。6月には, 試験運転を始める計画で あったが， 7 月になっても見通しさえつかない状態 であった。

理由を一言で言えば，業務の特殊性が原因であっ たが，外注で BASIC プログラムを開発できる所は， 実は殆ど無かった。実際にプログラムは，アルバイ トプログラムだったがこれは，私達もソフトハウス の実状に無知だったことが一つの原因であった。コ ボルなどの事務用言語ならプログラムは, 正社員と しても多かったのであろうが，それなら，言語にコ ボルを指定した方が良かったかと言うと、コボルプ ログラムに我々の全ての要求を達成させるには膨大 な経費がかかった上，消化不良のシステムになって いた恐れが感じられる。

外注プログラムで, システムの骨格は出来上がる が, 速度, 操作性で到底我々の満足できるものでは 無く, 運用開始が遅れるだけでなく，次第に実現そ のものが危がまれてくる中で，私は，外注に見切り を付け，8月より，自己開発に踏み切った。実際， 経済連の汎用機へのデータコンバートプログラムな どは，外注ではそこへ行き着くこともできなかった。 理由は，オフコン及びパソコンの両方の FD フォー マット及びコード形態を熟知し, 更に, ダイント にディスクの任意のセクタにデータを書き込むテク ニックなどは，正に，マニアの成せる技で，逆に正 統派（？）プログラムでは邪道のようなものだから かも知れない。

\section{5. 運用}

独自開発に切り替えてからは，順調に開発は進み 8 月中にデータ入力関係のプログラムを完成させ, 9 月にはデータ入力のテストを検査員記録と平行し ながら実施した。4月に新規で採用されたオペレー 夕職員が初めて本番を迎えることができた訳である。 1 週間ほどのテストで，ほほ満足できる機能を確認
できたので，それ以降は，手書き記録は一切廃止し， コンピュータ入力だけで対応している。

東計処理プログラムは, これに遅れ, 月末完成を 目指し並行開発することにした。フィードバック目 的など，日常の業務に関与しないプログラムは, 翌 年以降相当後になってから開発した。

$$
\text { 6.フィードパック }
$$

プログラム開発は前述のように, システム稼働そ のものが遅れていたので, フィードバックなどの応 用面関係プログラムは，とても着手できるような状 態ではなく，全て後回しとなった。これらのプログ ラムは, 約 1 年遅れて開発した。しかし, と畜検査 結果を畜産現場にフィードバックするという事例そ のものが少ないので, 当所で準備万端用意できた状 況になっても，実際にデータのフィードバックは殆 ど行われなかった。

フィードバックが日常的に行われるようになった のは, 所長, 係長が関係者講習会等機会ある毎に積 極的に, と畜検查データの活用のアピールを行って からで，昭和61年頃であった。

検查所におけると畜検查データの取扱いは，個人 データに属するという考えをもっており，その取扱 いには内規を策定し，慎重な取扱いを行っている。 基本的には, フィードバックを希望すると畜申請者 が，希望する範囲だけを提供している。

基本的姿勢として，と畜検查データには，如何に 潜在的価値があろうと,フィードバック事業は食肉 衛生検查所の本来の業務ではなく, と畜検査の時間 を裂いてまで行われるものではないとの考之を持っ ている。また, と畜検查データは, 病理解剖学的生 データである為, その理解・応用にはそれなりの専 門知識も必要である。そこで, 闇雲にデー夕を提供 するだけに終らないようにするために，専門知識を 有するコンサルタント的人材の確保か望まれる。そ ういう意味では, 家畜保健衛生所及び屡政課に事務 局を置く家畜防疫対策協議会などを通じたフィード バック事業は理想的形態と考えられる。また, 獣医 大学教育方面での活用・検討か望まれる。

\section{7 . 問題点}

このシステムは，迅速なデータ処理を目的に開発 したものであるが,一度磁気化されたデー夕は, 蓄 積を行ったものが考える以上に価值を発揮できるこ とを示しているように思われる。より多くのデータ 
が登録されればそれに越したことはないが，現実問 題を考えると, 欲張うたシステムより, 利用しやす いシステムの方が価值があると考えられる。

このシステムは, 我々の業務の中では完結したシ ステムで, これ以上の内部的発展は難しいと思われ るが，システム開発上あるいは将来的に問題が無い 訳ではない。問題点を, 幾つか挙げてみよう。

(1)自己開発である点

個人で利用するシステムならいざ知らず，公共の 業務に用いるプログラムが個人開発であることは非 常に問題である。このシステムのプログラム文字数 は, 何と170万文字にも達しており, その全貌を理解 しているのは, 私 1 人しか居ないので, 将来, 万が 一の事態が発生した場合の対処が非常に困難になる と思われる。このような事態になった原因を端的に 言えば, ソフト開発にかけた予算が余りにも低過ぎ たことにあるといえよう。これは, 我々の事前の調 查が行き届かず，認識不足だったことに由来するよ うに思われる。一般にハードウェアには十分な予算 を計上するのに比べ, ソフト費用が無視されがちな 傾向にあるが, このような認識はかえるべきで, 現 在はソフトに十分な予算をかけ，ハードウェアはそ のオマケ位に考えるべき時代になっていると思われ る。

この問題に対処する為の解決策として, プログラ ムに自己のシステムを認識させる機能を盛り込んで みた。これは, 将来, ハードウェア構成が変更され ても，簡単な手順で，そのシステムに移行できるよ うに考えられる。

(2)人事的問題

このシステムは, 全国食品衛生監視員協議会でも 優秀課題として表彰され，全国的にも知名度が高い。 従って，このシステムを取り入れようとする検査所 が増えているが, このシステムの技術面だけにしか 着目しない場合は, 失敗に終るか, あるいは期待し たような成果をあげられない恐れがある。と言うの は, システム設計の項で述べたように, 財政サイド は, 電算化を安直に人員削減に結びつけてしまうこ とが多いからである。その是非をここで云々するつ もりはないが, とにかく行政の中でこれを達成する には, 財政当局の理解を得なければならない。私の システム開発の目的は, 人員削減ではなく真の合理 化（高度化）にある。人員削減が目的では, 検查員 の協力はとうてい得られないと考えるべきである。 山本所長は, この件に次のような解決を見い出し
た。

正規獣医師 1 名 $=$ 嘱託獣医師 1 名

$$
\begin{aligned}
& \text { 十新規採用嘱託オペレーター } 2 \text { 名 } \\
& \text { 十無線システム } 1 \text { 式 } \\
& \text { +電算処理システム } 1 \text { 式 } \\
& \text { +精密検査機器の高度自動化 }
\end{aligned}
$$

この, 等式が妥当かどうかは, 現時点で云々でき るものではないが，財政サイドの顔を立てながらも， 現場で働く検查員に取っては返ってメリットになる 成果であり, 私としては, 行政機構の中で, この等 式を成立させた山本所長の手腕に，脱帽するだけで ある。これは, 本システム成功の，表には見えない 大きな要因である。

(3)フィードバックのあり方

フィードバックに対する期待が大きくなっている が，私は，安易にフィードバック業務をと畜検査に 取り入れていくことには疑問を持っている。ここで, 山本所長の日頃の言葉を借りてみる。

『高度情報化社会の到来で, 生産者が多くの情報を 収集できる現状にあって，更にと畜検査所見の生デ 一タがフィードバックにより入手できることは，経 営努力が一層促進され，より良い家畜の生産が期待 されるものである。これは, 食肉衛生検查所行政の 目的一安全で衛生的な食肉供給一が, 生産現場から 確保されることであり，その一助になり得るもので ある。

しかしながら, 生産者の一部には, ただ単に経済 的な廃棄の有無にのみ注目し, 原因たる疾病の有無 はもとより，畜舎の衛生管理等をなおざりにしてい る面がある。

フィードバックが, 真にその価值を発揮するため には, 先ず, 生産団体への指導は如何にあるべきか, 又, その経費と人員確保についても, 如何に取り扱 われるべきか等, 考えていかなければならない。』

この業務が検查所の業務であるように, 現時点で 思われる事には問題がある。検査所は, データバン クであるので, フィードバック事業の要には違いな いが, フィードバック事業の主体になるべきなら， その為の人員確保と予算計上が行われるべきである し，また，フィードバックが検査所の業務であると いう明確な根拠も必要となるであろう。

\section{8. 最後に}

このような発表の機会が得られたのは, 静岡県西 部家畜保健衛生所高見沢氏の推進するフィードバッ 
ク事業のおかげであると考えている。氏の精力的な ご努力により，居ながらにして，私たちの検查結果 の価値が高められていることに，大いに感謝してい る。

なお，家畜保健衛生所機構では，伝染病発生状況 等の情報を電話回線を利用し、リアルタイムに入手 できるような全国規模の通信ネットワークを実現し つつあるようであるが, このネットワークに, 食肉
街生検查所を含め，と亩検查結果の有効利用を図る ような構想実現もお願いしたい。

最後に, 検查所職員によると畜検查デー夕の活用 には，自ずから限界があると思われるので，このデ 一夕を如何に活かすべきかについて，是非とも皆様 のアイデアと屈託のないご意見をお願いします。

TRINET (0534) 49-4253 1200pbs N81XN

\section{9. 参考瓷料}

\section{1）西算化の歴史}

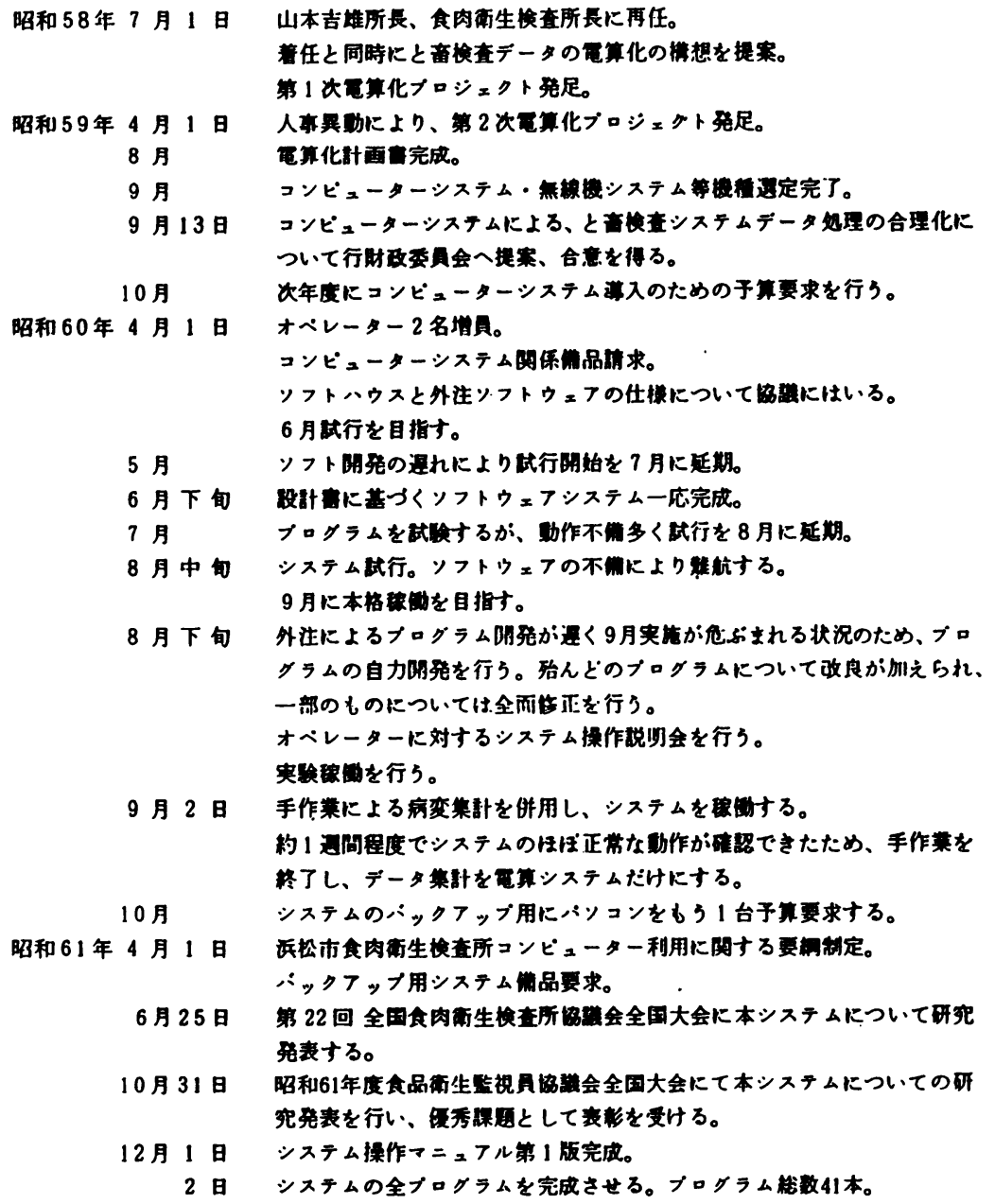

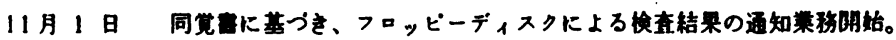

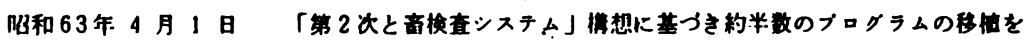
完了。今年度内完成を目指与。

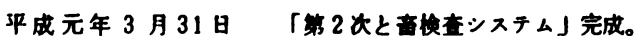


2）システム体系

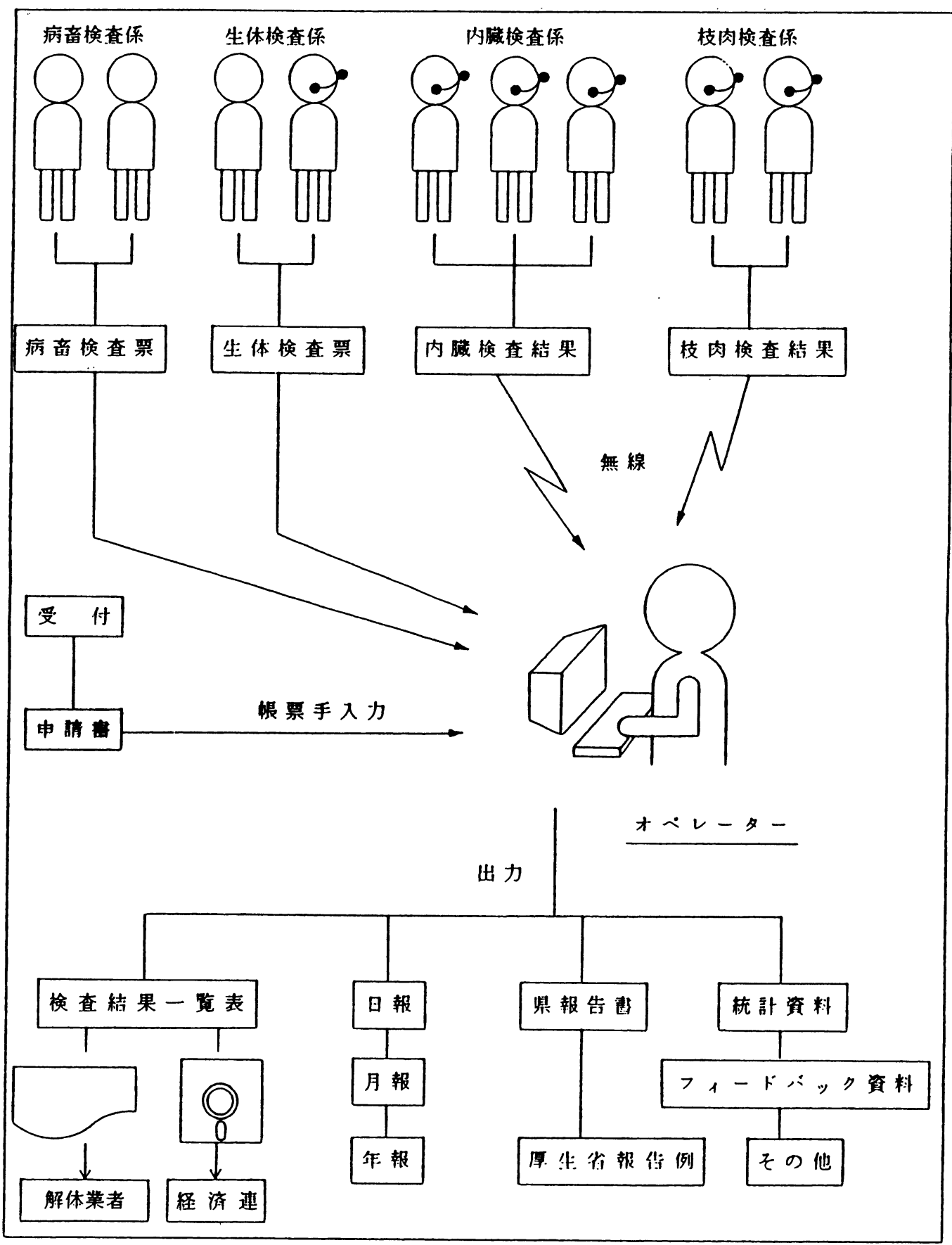


3）ハードウェアー管

\begin{tabular}{|c|c|}
\hline 称 & 型 \\
\hline 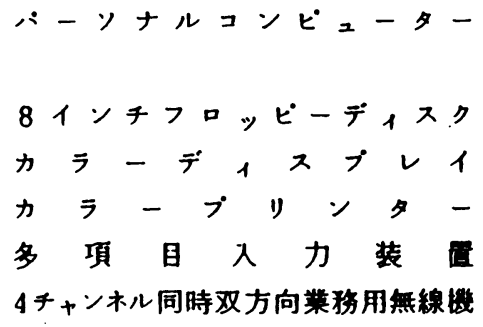 & 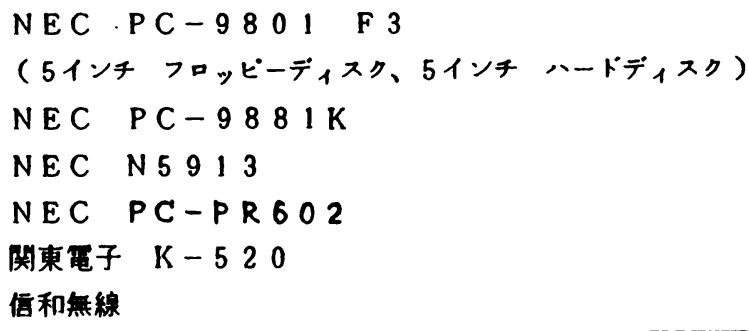 \\
\hline
\end{tabular}

4）ソフトウェア基本仕様

\begin{tabular}{|c|c|}
\hline 項 & 内 \\
\hline 使 用 媒 体 & 5インチ固定ディスク（ブログラム及びシステムフォイル用） \\
\hline & 8 8ンチフロッピーディスク（データフォイル用） \\
\hline $\mathrm{O}$ & 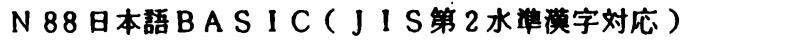 \\
\hline ブログラム数 & 52 本 \\
\hline$フ$ フルル数 & システム用：4本 データ用：10佰数 \\
\hline 容 & 8 8ンチフロッピーディスク1枚につき約 25,000颀/月 \\
\hline 登 録 内 容 & 表 5 吠 \\
\hline 出力槏式 & 表 7 照 \\
\hline コード表種類 & 病変コード400種・电請者コード400種 \\
\hline 及 び 数 & 処分コート5 50 種 \\
\hline
\end{tabular}

\section{5）登録内容}

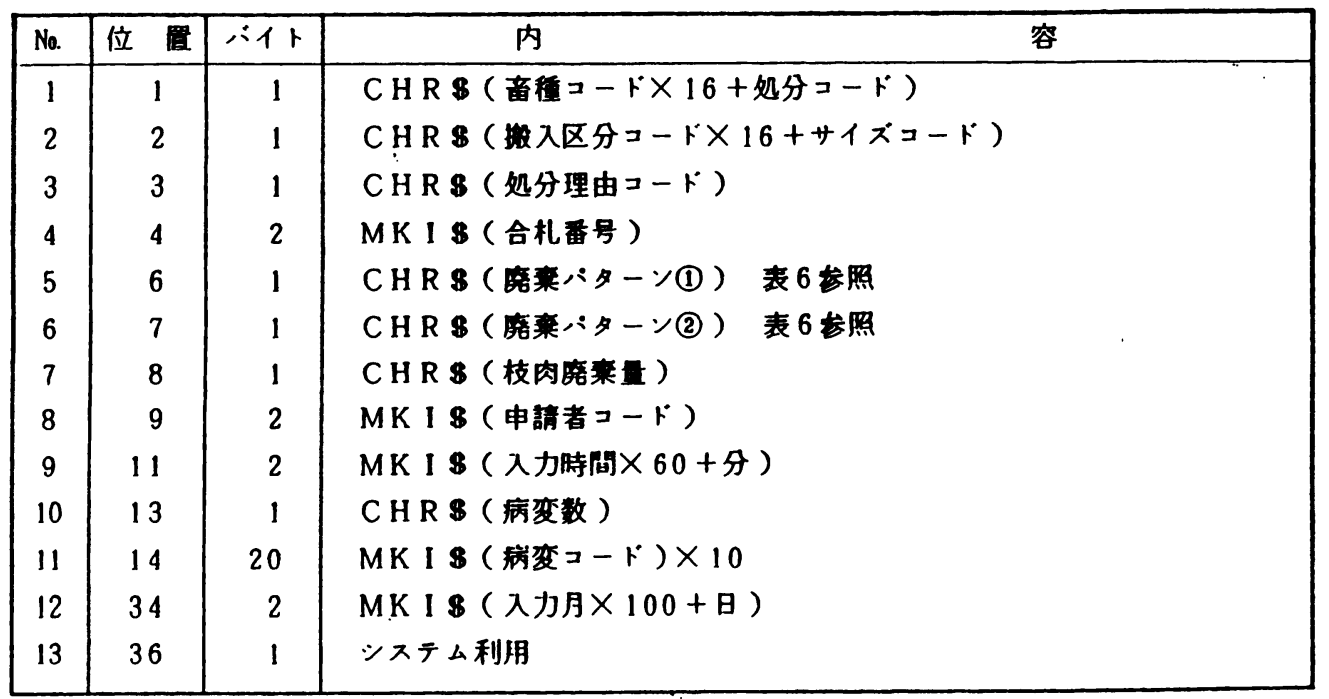


6）廃裹パターン

\begin{tabular}{|c|c|c|c|c|c|c|c|c|c|}
\hline 16 進 & 01 & 02 & 04 & 08 & 10 & 20 & 40 & 80 & \\
\hline L S B & 0 & 1 & 2 & 3 & 4 & 5 & 6 & 7 & M S B. \\
\hline (1) & 舌 & 心 & 朋 & 胃 & 】胃 & 四胃 & N胃 & 大晹 & \\
\hline (2) & 小腸 & 頭 & 皮 & 肢端 & 枝肉 & 枝全 & 舌残 & 内全 & \\
\hline
\end{tabular}

7）主な出力帳票の種類

\begin{tabular}{|c|c|}
\hline 日次処理関倸 & $\begin{array}{l}\text { 家畜別廃棄部位・病変集計表（対業者用） } \\
\text { 申請状況一筧表 } \\
\text { 日報概要（起案莗を兼ねる）・日報詳報 }\end{array}$ \\
\hline 月次処理関係 & $\begin{array}{l}\text { 月報概要（起案莗を兼机る）・月報群報 } \\
\text { 厚生省報告例集計（月報） }\end{array}$ \\
\hline 年次処理関俰 & 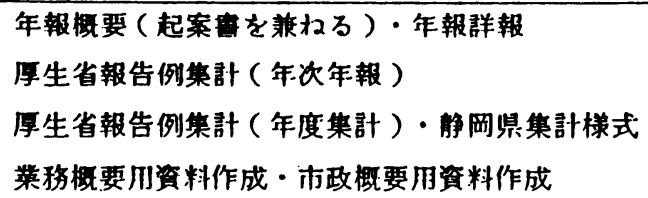 \\
\hline そ の 他 & $\begin{array}{l}\text { フィードシック用データの出カ } \\
\text { システムファイル打ち出し }\end{array}$ \\
\hline
\end{tabular}

8）コンピューターの利用に関する要網

(目 的)

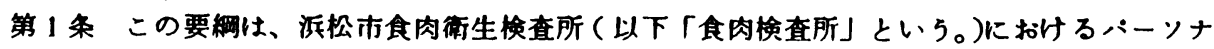
ルコンピューター（以下「パソコン」といら。）の利用について必要な事項を定めること により、その円滑かつ多目的利用の確保を四ることを目的とする。

(対象)

第 2 条この要網の対象は、食肉娭㚗所のパソコン（周辺機器を含む。）並びにこれに俰るブロ グラム及びデータとする。

(パソコンの利用)

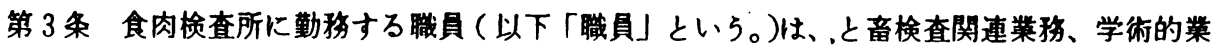
務その他必要な業務のためパンコンを利用することができる。

2. 職員以外の者は、次の事項を記载した曹面により所長の詐可を受けてパンンを利用 ナることがでる。
(1) 所属及び氏名
(2) 利用日時及び時間
(3) 利用目的

( 利用の順位 )

第 4 条 パソコンを利用しようとナる者が複数の場合の優先順位は、次のとおりとし、同一莱 務については、申込み順とする。

(1) と音娭㚗関連業務

(2) 事務処理莱務

(3) 学術的莱務

(4) その他の莱務

(パソコンの取报い) 
第 5 条 パソコンを使用する者（以下「利用者」といら。）は、パソコン及び使用するンフトウ ェフーについてあらかじめ整知しておかなければならない。

2. 利用者は、ハンンンの利用後は使用暗の状態に杘しておかなければならない。

( 禁止事項)

第 6 条利用者は、次の各甼に揭げる行為を行ってはならない。

(1) 業枒で使用する.ブログラム及びデータにむやみに手を加えること。

(2) 他の者が作成したプログム及びデータに作成者の作可なくむやみに手を加えるこ r。

(3) パソコンの機能に障害を与えるおてれのある行為をすること。

(プログラムの管理 )

第 7 条 菜務で使用するプログラムは、所長の部可なく数製し、又は公開してはならない。

(データの管理 )

第 8 条業弱によって作成されたデータは、所長の許可なく公閒してはならない。

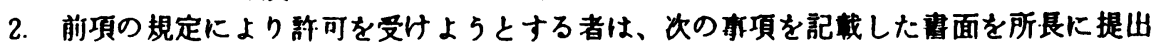
しなければならない。

(1) 所属及び氏名

(2) 利用目的

(3) 公開を希望するデータの種類及びその内容

3. 所長は、データの公開が個人のブライバシーを很害するおそれがあるときその他第三 者の権利を侵害するおそれがあるときは、第1項の許可をしない。

(紴目)

第 9 条この要網に定めるもののはか、必要な事项は、所長が定める。

附則この要網は、炤和61年4月1日から施行する。 